\title{
Black College Alumni Giving: A Study of the Perceptions, Attitudes, and Giving Behaviors of Alumni Donors at Selected Historically Black Colleges and Universities
}

Received (in revised form): June 29, 2006

\section{Rodney T. Cohen}

has over a decade of professional experience in higher education including positions at Notre Dame, Western Kentucky, UT Medical Branch, North Carolina A\&T, Fisk, and the Washington Center for Internships. He has researched and lectured on the history, culture, and traditions of HBCUs. His work has resulted in articles and the publication of two books on black colleges: The Black Colleges of Atlanta (2000) and Fisk University (2001). He has been an invited guest lecturer and keynote speaker for numerous colleges and organizations including Black Enterprise Magazine, Central Missouri State University, Saint Mary's College, Georgia College, Morehouse College, and Columbia University. He is a graduate of Clark College in Atlanta, Western Kentucky, and Vanderbilt Universities, where he received his bachelor, master, and doctorate degrees, respectively.

\begin{abstract}
Historically, Historically Black Colleges and Universities (HBCUs) have struggled in their attempt to solicit financial gifts from its alumni. Traditionally, black college alumni have appeared to show negligence in their effort to support their alma maters. As a result, many black colleges have ignored them as potential donors. This lack of attention may be crucial to the very survival of HBCUs. Historically, many of these colleges have depended on the support of foundations and corporations. However, with the shift in funding
\end{abstract}

Author's Contact Address: Rodney T Cohen 2925 Peek Road NW Atlanta, GA 30318 USA Phone: +18324075255 Email: tandy27@mindspring.com priorities by many foundations and corporations and an increased competition for support by other institutions, funding from these funding sources has become limited and in some cases nonexisting. Therefore, the need for many HBCUs to garner financial support from its alumni is vital for their survival. The purpose of this study was to improve on the knowledge and understanding regarding black college alumni as it relates to their alma mater and the philanthropic process. Since contributions from alumni play such a significant role in the life of an institution, the question is "what can be expected from alumni giving at black colleges in the coming decades?" In response, this study sought to investigate the perceptions, attitudes, and giving behaviors of alumni donors 
at a selected group of HBCUs. The research study was conducted among 1000 alumni donors of four historically black colleges and universities. The results of the study uncovered some interesting findings, which paralleled and contradicted some previous studies dedicated to African American giving. The findings uncovered the fact that alumni literature has not influenced them to give financially. Although alumni donors in this study tended to show high levels of dedication and desire towards giving, however, they felt that their alma mater could exist in the future without their support. Finally, alumni believed that their alma mater was not in the best position financially. Consistent with past studies regarding African American philanthropy, alumni in this study support the church almost four times that of the alma mater.

International Journal of Educational Advancement (2006) 6, 200-220. doi:10.1057/palgrave.ijea.2150030

\section{Keywords:}

Black Colleges and Universities, alumni giving, HBCUs, alumni attitudes, Black college alumni

\section{Introduction}

Arguably, one of the most glaring problems facing Historically Black Colleges and Universities (HBCUs) in the twenty-first century is the problem of limited alumni giving. Unlike many of its traditional white institution counterparts, HBCUs have struggled in their attempt to solicit consistent and substantial financial gifts from their alumni. In today's competitive climate of fund raising, such a challenge has several implications.

One implication relates to how an institution utilizes alumni support to make a case for additional funding. Many funding institutions, such as foundations and corporations, look to alumni support as an indicator when considering a major gift to that institution (Stutler and Calvario, 1996). In addition, alumni giving and participation serve as the most significant indicators of the esteem held by any group of individuals towards its alma mater (Shadoian, 1989).

Although individual contributions to HBCUs have increased somewhat over the last decade, its consistency and impact continues to lag drastically. Traditionally, HBCUs have struggled to obtain major alumni support. Over seven decades ago W.E.B. DuBois challenged his fellow alumni of Fisk University to support their alma mater. He stated "very little" of the University's "new million dollar endowment has come from us." (DuBois, quoted in Aptheker, 1973, p. 58). This perception continues to persist when financial support and HBCUs are mentioned.

Therefore, the question "why don't blacks support Tuskegee, Morehouse, Spelman, Howard," can be answered in many ways (Lee and Jones, 1988, p. 205). Some suggest that it is an issue of limited resources in the black community while others point to the negligence of HBCUs to systematically cultivate and solicit their alumni (Byrd, 1999).

Although consistent alumni giving can serve a similar function to that of the earnings gained from an endowment, HBCUs have 
systematically replaced their alumni with corporate donors as the main source of funding ("Fund-raising Pressures,"2002). The old adage of "it takes money, to make money," poses a serious dilemma for the average HBCU. According to Gasman (2002), "it takes more money to go out there and ask and cultivate alumni donors than it does to get one big corporate donor" (p. 280). The move to concentrate heavily on foundation and corporate support in lieu of alumni may be crucial to the very survival of HBCUs. In fact, with the shift in priorities by many foundations and corporations, funding may become limited and in some cases nonexistent.

Therefore, the need for consistent financial support from alumni is almost vital to the very survival of black colleges. A select group of black colleges such as Spelman, Howard, and Hampton have made significant financial strides over the last decade, atypical of most HBCUs; their success, however, has been a result not largely due to the financial contribution of their alumni (Winbush, 1996). For example, in 1996, at the close of the Spelman College Campaign, alumnae contributed an average gift of $\$ 170$ per living alumnae, equaling less than 3 percent of the total $\$ 114$ million raised in the largest comprehensive campaign for a black college at that time ("Alumni of Black Colleges," 1996). Such figures appear even more challenging when compared to the support received from the alumnae of Wellesley College, during its campaign. For its comprehensive campaign during the same period, Wellesley received 80 percent of its $\$ 168$ million from alumnae ("Alumni of Black Colleges,” 1996).
Even with the recent financial successes of HBCUs like Spelman, Morehouse, Howard, and Hampton, the need for consistent and substantial support from alumni is almost vital to their survival. Although HBCUs have persisted and existed on meager budgets since 1837 , today's climate of competition will no longer support the existence of these colleges on such budgets and may ultimately result in their closure. Since the intent of this study was to add to the literature and provide insight and recommendations related to HBCU alumni, the focus geared toward investigating a plethora of perceptions, attitudes, and giving behaviors associated with alumni donors at a selected group of HBCUs.

\section{Conceptual Framework}

The direction of this study was driven by the philosophy of Seymour that "in organized fund-raising... a good way to begin is to learn as much as you can about people" $(1992$, p. 3$)$. In the case of this study, the researcher wanted to explore those alumni currently vested as givers and investigate their perceptions, attitudes, and giving behaviors. In addition, similar to other studies related to black philanthropy (Gasman, 2002; Russell and Kasberg, 1997), this study also sought to uncover the rich potential of black alumni to support their alma maters significantly, given the sufficient type of data required for proper cultivation. A review of the literature on black philanthropy revealed that studies have mostly looked at philanthropy in the black community in terms of charity, volunteerism, religion, and civic and social organizations, but research related to 
higher education is scant and almost nonexistent when investigating alumni givers as vested stakeholders and understanding their voice as it relates to the overall philanthropic process specific to their alma maters.

Owing to the ongoing changes in the American economy, many colleges and universities have had to redefine how they anticipate revenue.

Endowments are shrinking, and nearly all institutions have experienced a decline in their portfolios ("What is Happening," 2003). As a result, institutions are relying more on their alumni for immediate and long-term support. Donor (alumni)-centered programs in higher education can expect to weather the storm by working on prospect research, obtaining donor feedback data, reinforcing long-term development work, consistent communication with alumni, and involving alumni in the continued life of the institution ("What is Happening," 2003). As the HBCUs continues its survival in the competitive era of higher education, its survival will in some cases rely largely on the development of its alumni as a consistent donor base. As a result, much of the time-tested techniques employed in the institutional advancement profession must be strongly considered as an option for the remaining HBCUs. However, due to the uniqueness of HBCUs and their alumni, black colleges must be aware of the differences that may exist in their alumni and respond accordingly when involving them in the philanthropic process.

\section{Research method}

Drawing on the previous studies of Bremond (1976), Hodgkinson and
Weitzman (1992), Okunade (1996), Russell and Kasberg (1997), Eckel and Grossman (1998), Clotfelter (2000), and Gasman (2002) conducted related to philanthropy in the African American and minority communities, this study utilized the descriptive design of research in order to obtain information through interviews or mailed surveys (Miller and Salkind, 2002). In the case of this study, mailed surveys were utilized.

The questionnaire utilized in this study was an original survey developed to ascertain data specific to the attitudes, perceptions, and giving behaviors of African American alumni donors of a selected group of HBCUs in order to address the following research questions:

- What is the relationship between the level of alumni giving of black college alumni and their perceptions of alumni communications at their alma mater?

- What is the relationship between the level of alumni giving of black college alumni and their perceptions regarding the philanthropic process at their alma mater?

- What is the relationship between the level of alumni giving of black college alumni and their attitudes towards giving to their alma mater?

- What is the relationship between the level of alumni giving of black college alumni and their giving behaviors related to their alma mater?

- What is the relationship between the level of alumni giving of black college alumni and their giving patterns to other organizations? 


\section{Sample}

The questionnaire was administered to a select group of alumni donors from four HBCUs. For the reason of maintaining anonymity consistent with the research agreement, the HBCUs of which the names were obtained will remain confidential; however, an overview and general description of the participating institutions are outlined in order to provide an institutional profile of the respondents' alma maters (Table 1 ).

The sample consisted of alumni donors of the four selected HBCUs. Because the numbers of alumni donors varied, a judgmental sample was utilized to allow for a subgroup to be selected on the basis of the information available (Miller and Salkind, 2002). A sample of 250 alumni donors was obtained from each of the four HBCUs, producing a total of 1,000 potential participants to receive surveys. The survey was mailed to 1,000 individuals along with a cover letter. The survey was a six-page questionnaire, which was developed by the researcher based on prior research and pretested as a pilot.

The survey consisted of six sections with a total of 48 questions. Section I was made up of eight questions that obtained demographic information of the respondents, such as gender, race, age, and income. Section II consisted of eight questions related to perceptions on how one's alma mater communicates with them as an alumna/alumnus. Questions on issues such as, "I receive alumni correspondence from my alma mater regularly," and "I feel well informed about the current affairs of my alma mater," were asked. Section III consisted of eight questions related to the perceptions of alumni on the philanthropic process at their alma mater. Section IV consisted of 12 questions related to one's attitude toward giving to one's alma mater. Section V consisted of seven questions focusing on giving behaviors and patterns. Section VI focused on information related to financial giving with five questions. Sections II-V utilized a four-point, Likert-type scale to elicit responses: 1 (strongly agree), 2 (agree), 3 (disagree), and 4 (strongly disagree).

\section{Analyses}

Following data collection, a $t$-test procedure was conducted to examine the research questions. More specifically for this study, an

Table 1: Institutional profile

\begin{tabular}{lllllll}
\hline Institution & Type & $\begin{array}{l}\text { Founding date } \\
\text { (circa) }\end{array}$ & Enrollment & $\begin{array}{l}\text { Average alumni } \\
\text { giving (\%) }\end{array}$ & $\begin{array}{l}\text { Endowment } \\
\text { (\$ in million) }\end{array}$ & Living alumni \\
\hline I & $\begin{array}{l}\text { Liberal Arts } \\
\text { Master's }\end{array}$ & 1870 & 427 & 13 & 10 & 5,000 \\
II & $\begin{array}{l}\text { Regional } \\
\text { Doctoral }\end{array}$ & 1890 & 8,400 & 12 & 14 & 28,000 \\
III & $\begin{array}{l}\text { National } \\
\text { Baccalaureate } \\
\text { Comprehensive }\end{array}$ & 1880 & 4,500 & 2 & 35 & 23,000 \\
IV & & 1,200 & 8 & 3 & 7,500 \\
& & & & & & \\
\hline
\end{tabular}


independent-samples $t$-test was utilized. The independent samples $t$-test allows for comparison of the means of one variable for two groups of cases (SPSS, 1999).

The two groups in the study were defined as low givers and high givers. The low givers were identified by those respondents who reported a five-year cumulative gift to their alma maters totaling $\$ 999$ or less, whereas high givers were defined as those respondents who reported a five-year cumulative gift to their alma maters totaling $\$ 1,000$ or more.

\section{Limitations}

The study had limitations in three areas. These included the number of institutions used, the sample, and the low response yield. For reasons mentioned earlier in this study, only four institutions out of a total number of 89 eligible HBCUs were utilized to obtain sample groups.

The limitation of the sample was two-fold: First, the only alumni eligible to receive a survey were those who had made a contribution within a fiveyear period of the study. This stipulation eliminated a large contingent of nondonors. Second, the database of alumni provided by the participating institutions resulted in a limitation due to the challenges of data accuracy.

The low yield (12 percent) of completed surveys provided a limitation. Generally speaking, however, mail surveys tend to produce a low yield, particularly in a highly competitive environment (Miller and Salkind, 2002). According to Wallace (1954), the mail survey may often provide a response rate not exceeding 50 percent. Although the low response rate posed a limitation, it may provide insight for future research as outlined later.

\section{Findings}

\section{Perceptions Regarding Alumni Communications}

With regard to alumni communications (see Table 2), the participants were asked to respond to questions that investigated the manner in which their alma mater communicates with them as alumni and potential donors. Communications, in the case of this study, were categorized into various types of literature received by alumni, which may have prompted them to give financially to their alma mater. Additionally, alumni were asked to indicate if they received

communications informing them about various aspects of "institutional advancement," including Alumni Affairs, the annual fund, and information pertaining to a capital campaign.

Alumni perceptions about the "regularity of communications" from their alma mater, regardless of the giving level-high versus low-were generally positive (see Table 3 ). They felt that their alma mater sends alumni correspondence with some regularity and that the information they received was not only when their alma mater was "asking for money." Further findings from the $t$-test analysis, however, indicated a difference in the perceptions between high and low givers. The findings suggest that although low givers felt well informed about the affairs at their alma mater, they were not necessarily encouraged or prompted to give because of the amount of correspondence received. 
Table 2: Perceptions of how one's alma mater communicates with their alumni

\begin{tabular}{|c|c|c|c|c|c|c|c|c|c|c|}
\hline \multirow[b]{3}{*}{ Question } & \multicolumn{10}{|c|}{ Response } \\
\hline & \multicolumn{2}{|l|}{ SA } & \multicolumn{2}{|l|}{ A } & \multicolumn{2}{|l|}{ D } & \multicolumn{2}{|l|}{ SD } & \multicolumn{2}{|c|}{ NR } \\
\hline & $n$ & $\%$ & $n$ & $\%$ & $n$ & $\%$ & $n$ & $\%$ & $n$ & $\%$ \\
\hline $\begin{array}{l}\text { I receive alumni correspondence from my } \\
\text { alma mater regularly }\end{array}$ & 38 & 39.6 & 39 & 40.6 & 6 & 6.3 & 8 & 8.3 & 5 & 5.2 \\
\hline $\begin{array}{l}\text { The only time I receive information from } \\
\text { my alma mater is when they are asking for } \\
\text { money }\end{array}$ & 8 & 8.3 & 10 & 10.4 & 44 & 45.8 & 28 & 29.2 & 6 & 6.3 \\
\hline $\begin{array}{l}\text { I feel well informed about the current affairs } \\
\text { of my alma mater }\end{array}$ & 23 & 24.0 & 39 & 40.6 & 23 & 24.0 & 7 & 7.3 & 4 & 4.1 \\
\hline $\begin{array}{l}\text { My alma mater has been in contact with me } \\
\text { since I graduated }\end{array}$ & 40 & 41.7 & 39 & 40.6 & 6 & 6.3 & 5 & 5.2 & 6 & 6.2 \\
\hline $\begin{array}{l}\text { Materials and literature that I receive from } \\
\text { my alma mater have prompted me to give } \\
\text { annually }\end{array}$ & 14 & 14.6 & 25 & 26.0 & 36 & 37.5 & 13 & 13.5 & 8 & 8.4 \\
\hline $\begin{array}{l}\text { I receive, regularly, information from my } \\
\text { alma mater informing me about the mission } \\
\text { and working of the Office of Alumni Affairs }\end{array}$ & 13 & 13.5 & 40 & 41.7 & 26 & 27.1 & 11 & 11.5 & 6 & 6.2 \\
\hline $\begin{array}{l}\text { I receive regular correspondence about the } \\
\text { college Annual Fund }\end{array}$ & 19 & 19.8 & 45 & 46.9 & 16 & 16.7 & 9 & 9.4 & 7 & 7.2 \\
\hline $\begin{array}{l}\text { Since I graduated, I have received } \\
\text { information regarding a capital campaign }\end{array}$ & 16 & 16.7 & 38 & 39.6 & 21 & 21.9 & 11 & 11.5 & 10 & 10.3 \\
\hline
\end{tabular}

Note: $\mathrm{SA}=$ strongly agree; $\mathrm{A}=$ agree; $\mathrm{D}=$ disagree; $\mathrm{SD}=$ strongly disagree; $\mathrm{NR}=$ no response

\section{Perceptions Related to the Philanthropic Process}

In this section, alumni were asked questions about the philanthropic process-those activities and departments associated with facilitating giving to their alma mater. More specifically, alumni perceptions related to endowment, funding, and development activities at their alma mater were investigated. As shown in Table 4, the findings suggested that regardless of the giving level, the alumni believed that their alma mater could "survive" in the future "without their financial support." The findings also suggested that the alumni, regardless of the giving level, are "clear about" what "an annual fund" is at their alma mater, but "unclear" on what "a capital campaign" is.

With regard to the differences found between high givers and low givers (see Table 5), the findings suggested that a significant majority of the low givers felt that "the endowment" of their alma maters was "not adequate" and that the "funding currently received" by their alma 
maters is "not adequate." Low givers indicated generally that they were aware of the development activities at their alma maters. In terms of being an active alumnus/a, as defined by membership in an alumni association, a majority of low givers indicated that they held membership in their alumni association and that they were aware of the benefits afforded them as members.

\section{Attitudes Towards Giving to Alma Mater}

This section investigated attitudes towards giving. Irrespective of giving levels, both high and low givers believe that "giving back" is defined as more

Table 3: $t$-Test analysis: perceptions of how one's alma mater communicates with their alumni

\begin{tabular}{lccccc}
\hline Variable & $n$ & $M$ & $t$-value & df & $p$-value \\
\hline I receive alumni correspondence & from my alma mater regularly & & \\
High givers & 26 & 1.94 & -1.75 & 0.80 & 0.084 \\
Low givers & 56 & 1.57 & &
\end{tabular}

The only time I receive information from my alma mater is when they are asking for money

$\begin{array}{llllcl}\text { High givers } & 27 & 3.11 & 0.32 & 41.03 & 0.745 \\ \text { Low givers } & 55 & 3.03 & & & \end{array}$

I feel well informed about the current affairs of my alma mater

$\begin{array}{llllll}\text { High givers } & 27 & 1.85 & -2.21 & 0.81 & 0.029^{*} \\ \text { Low givers } & 56 & 2.30 & & \end{array}$

My alma mater has been in contact with me since I graduated

$\begin{array}{llllll}\text { High givers } & 27 & 1.40 & -2.31 & 0.79 & 0.023 *\end{array}$

Low givers $\quad 54$

Materials and literature that I receive from my alma mater have prompted me to give annually
High givers
27
2.01
$-3.90$
0.78
$0.001^{* *}$

Low givers

54

2.83

I receive, regularly, information from my alma mater informing me about the mission and working of the Office of Alumni Affairs

$\begin{array}{llllll}\text { High givers } & 25 & 2.03 & -2.44 & 0.8 & 0.017^{*} \\ \text { Low givers } & 55 & 2.53 & & \end{array}$

I receive regular correspondence about the college Annual Fund

$\begin{array}{llllll}\text { High givers } & 27 & 1.81 & -2.60 & 0.80 & 0.001^{* *}\end{array}$

Low givers $\quad 55 \quad 2.32$

Since I graduated, I have received information regarding a capital campaign

$\begin{array}{llllll}\text { High givers } & 26 & 1.96 & -2.30 & 0.76 & 0.024 * \\ \text { Low givers } & 52 & 2.46 & & & \end{array}$

*Significance $<0.05$, two-tailed

$*$ Significance $<0.01$, two-tailed 


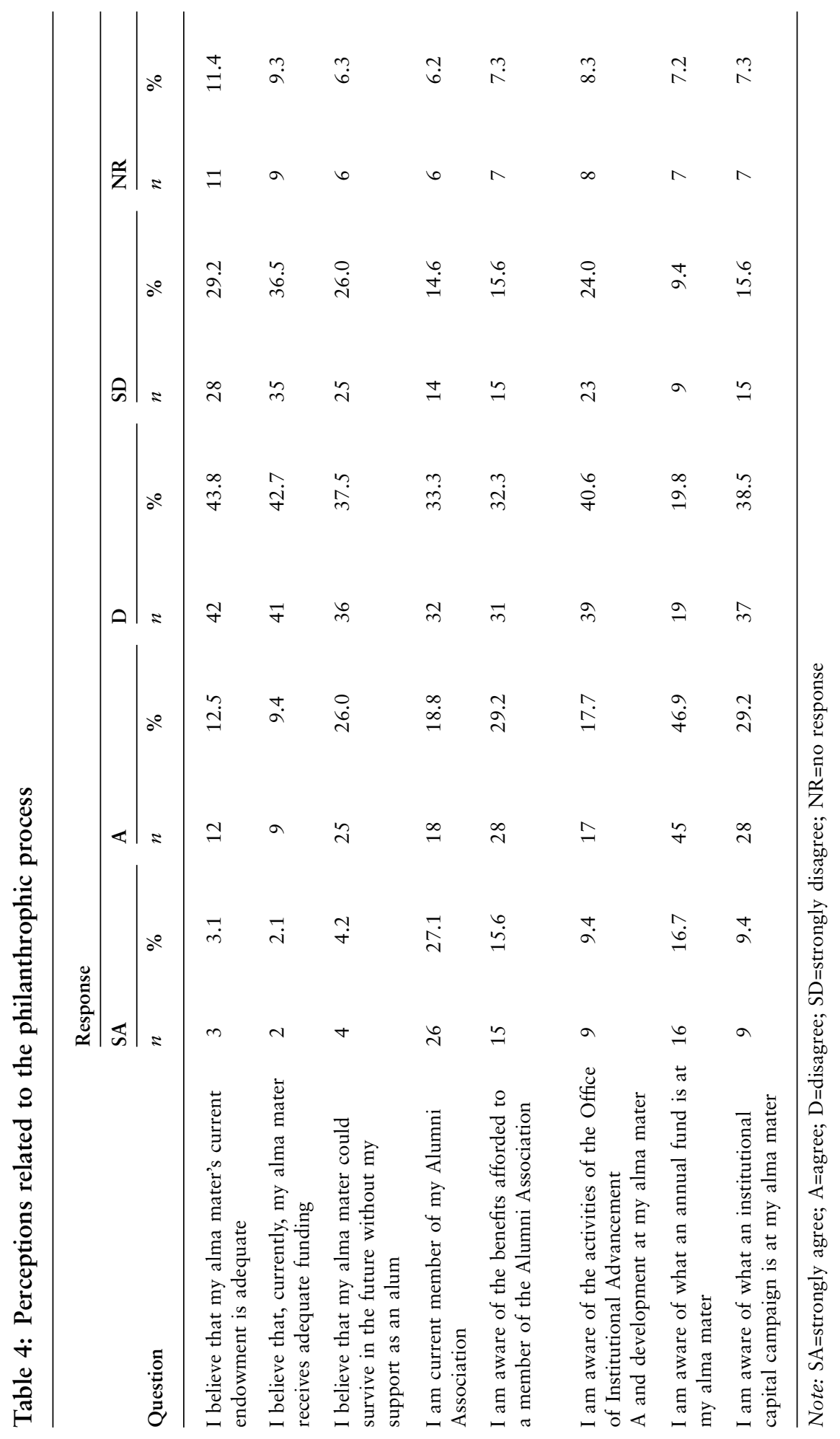


Table 5: $t$-test analysis: perceptions related to the philanthrophic process

\begin{tabular}{lccccc}
\hline Variable & $n$ & $M$ & t-value & df & \\
& & & \\
I believe thalue
\end{tabular}

I believe that, currently, my alma mater receives adequate funding

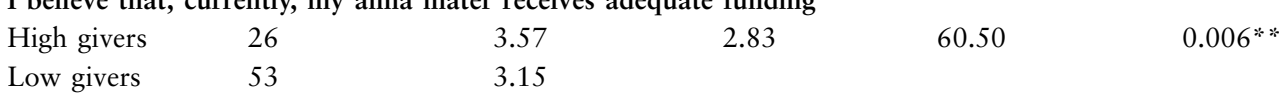

I believe that my alma mater could survive in the future without my support as an alum

$\begin{array}{llllll}\text { High givers } & 26 & 3.15 & 1.44 & 0.79 & 0.154\end{array}$

Low givers $\quad 55$

I am current member of my Alumni Association

$\begin{array}{llllll}\text { High givers } & 26 & 1.61 & -4.92 & 52.24 & 0.001^{* *}\end{array}$

Low givers $\quad 54$

I am aware of the benefits afforded to a member of the Alumni Association

$\begin{array}{llllll}\text { High givers } & 25 & 1.96 & -3.65 & 0.78 & 0.001^{* * *} \\ \text { Low givers } & 55 & 2.76 & & \end{array}$

I am aware of the activities of the Office of IA and development at my alma mater

$\begin{array}{llllll}\text { High givers } & 25 & 2.48 & -2.3 & 0.78 & 0.024 \text { * }\end{array}$

Low givers $\quad 55$

I am aware of what an annual fund is at my alma mater

$\begin{array}{llllll}\text { High givers } & 27 & 2.01 & -1.62 & 0.79 & 0.109 \\ \text { Low givers } & 54 & 2.33 & & & \end{array}$

I am aware of what an institutional capital campaign is at my alma mater

$\begin{array}{llllll}\text { High givers } & 25 & 2.44 & -1.81 & 0.78 & 0.161 \\ \text { Low givers } & 55 & 2.74 & & & \end{array}$

*Significance $<0.05$, two-tailed

$* *$ Significance $<0.01$, two-tailed

than just giving financially; in fact, they indicate that they would currently send their son, daughter, or a close relative to their alma mater; and if they "had it to do over again," they would choose to attend their alma mater (see Table 6).

Surprisingly, as shown in Table 7 , the findings indicated that a majority of low givers disagreed with the statement that "only the wealthy can make a contribution." Although the low givers in the study indicated a financial gift of less than $\$ 999$ over a five-year period to their alma maters, the majority indicated that they "do feel financially able" to make a contribution to their alma maters.

Low givers' attitudes also appear positive with regard to "institutional worthiness," whether or not my alma mater is "worthy" to receive my 


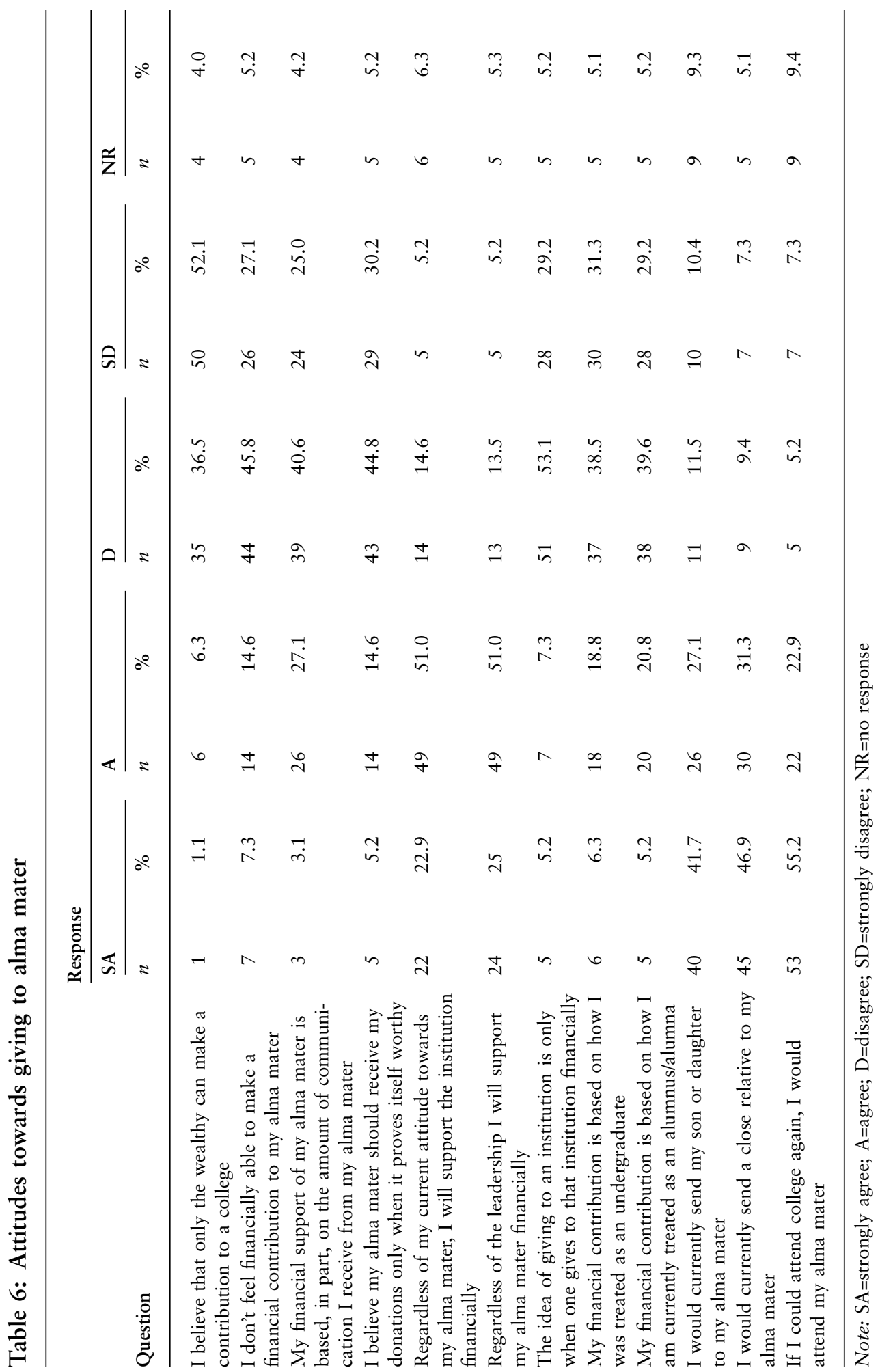


Table 7: $t$-test analysis: attitudes towards giving to alma mater

\begin{tabular}{|c|c|c|c|c|c|}
\hline Variable & $n$ & $M$ & $t$-value & df & $p$-value \\
\hline \multicolumn{6}{|c|}{ I believe that only the wealthy can make a contribution to a college } \\
\hline High givers & 27 & 3.96 & 5.05 & 0.81 & $0.001 * *$ \\
\hline Low givers & 56 & 3.26 & & & \\
\hline \multicolumn{6}{|c|}{ I don't feel financially able to make a financial contribution to my alma mater } \\
\hline High givers & 26 & 3.69 & 5.99 & 0.82 & $0.001 * *$ \\
\hline Low givers & 56 & 2.66 & & & \\
\hline
\end{tabular}

My financial support of my alma mater is based, in part, on the amount of communication I receive from my alma mater

High givers

$27 \quad 3.25$

3.25
2.73

2.91

0.81

$0.005 *$

Low givers

56

I believe my alma mater should receive my donations only when it proves itself worthy

$\begin{array}{llllll}\text { High givers } & 27 & 3.37 & 2.49 & 0.80 & 0.015^{*} \\ \text { Low givers } & 55 & 2.89 & & \end{array}$

Low givers $\quad 55 \quad 2.89$

Regardless of my current attitude towards my alma mater, I will support the institution financially

$\begin{array}{lllllr}\text { High givers } & 27 & 1.74 & -2.33 & 0.79 & 0.022 * \\ \text { Low givers } & 54 & 2.18 & & & \end{array}$

Low givers $\quad 54$

Regardless of the leadership I will support my alma mater financially

$\begin{array}{llllll}\text { High givers } & 25 & 1.66 & -2.76 & 0.80 & 0.007^{* *} \\ \text { Low givers } & 55 & 2.18 & & \end{array}$

The idea of giving to an institution is only when one gives to that institution financially

$\begin{array}{llllll}\text { High givers } & 27 & 3.14 & -0.07 & 0.81 & 0.946\end{array}$

Low givers $\quad 55$

My financial contribution is based on how I was treated as an undergraduate

$\begin{array}{llllll}\text { High givers } & 27 & 3.38 & 2.71 & 0.80 & 0.008^{* *} \\ \text { Low givers } & 56 & 2.8 & & \end{array}$

My financial contribution is based on how I am currently treated as an alumnus/ae

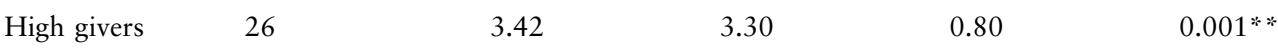

Low givers $\quad 56$

I would currently send my son or daughter to my alma mater

$\begin{array}{llllll}\text { High givers } & 24 & 1.66 & -1.30 & 0.77 & 0.194\end{array}$

Low givers $\quad 55 \quad 2.01$

I would currently send a close relative to my alma mater

$\begin{array}{llllll}\text { High givers } & 26 & 1.46 & -1.94 & 0.80 & 0.055\end{array}$

Low givers $\quad 56$

If I could attend college again, I would attend my alma mater

$\begin{array}{llllll}\text { High givers } & 25 & 1.44 & -1.29 & 0.77 & 0.201 \\ \text { Low givers } & 54 & 1.72 & & & \end{array}$

\footnotetext{
*Significance $<0.05$, two-tailed

$*$ Significance $<0.01$, two-tailed
} 


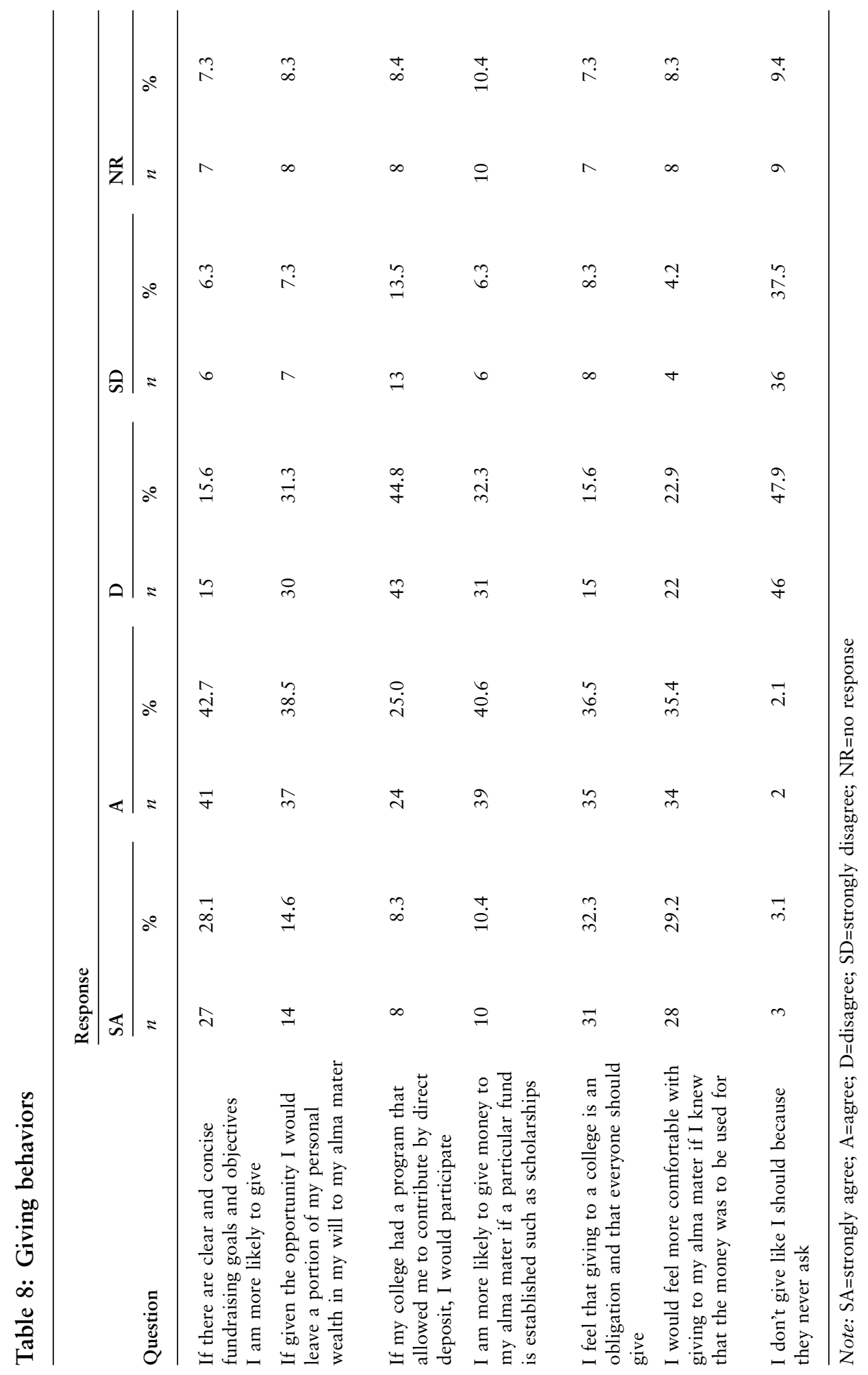


Table 9: $t$-Test analysis: giving behaviors

\begin{tabular}{|c|c|c|c|c|c|}
\hline Variable & $n$ & M & $t$-value & df & $p$-value \\
\hline \multicolumn{6}{|c|}{ If there are clear and concise fundraising goals and objectives I am more likely to give } \\
\hline High givers & 26 & 1.73 & -1.62 & 0.80 & 0.108 \\
\hline Low givers & 56 & 2.05 & & & \\
\hline \multicolumn{6}{|c|}{ If given the opportunity I would leave a portion of my personal wealth in my will to my alma mater } \\
\hline High givers & 26 & 1.96 & -2.76 & 0.79 & $0.007 * *$ \\
\hline Low givers & 55 & 2.50 & & & \\
\hline \multicolumn{6}{|c|}{ If my college had a program which allowed me to contribute by direct deposit I would participate } \\
\hline High givers & 26 & 2.61 & -0.37 & 0.79 & 0.712 \\
\hline Low givers & 55 & 2.69 & & & \\
\hline \multicolumn{6}{|c|}{ I am more likely to give money to my alma mater if a particular fund is established such as scholarships } \\
\hline High givers & 25 & 2.40 & 0.31 & 0.08 & 0.760 \\
\hline Low givers & 53 & 2.33 & & & \\
\hline \multicolumn{6}{|c|}{ I feel that giving to a college is an obligation and that everyone should give } \\
\hline High givers & 27 & 1.59 & -2.76 & 53.98 & $0.008 * *$ \\
\hline Low givers & 56 & 2.17 & & & \\
\hline \multicolumn{6}{|c|}{ I would feel more comfortable with giving to my alma mater if I knew that the money was to be used for } \\
\hline High givers & 25 & 2.12 & 0.73 & 0.79 & 0.469 \\
\hline Low givers & 56 & 1.96 & & & \\
\hline \multicolumn{6}{|c|}{ I don't give like I should because they never ask } \\
\hline High givers & 25 & 3.48 & 1.44 & 0.78 & 0.153 \\
\hline Low givers & 55 & 3.23 & & & \\
\hline
\end{tabular}

$*$ *Signifance $<0.01$, two-tailed

financial contribution. A majority of the low givers indicated that they "would support" their alma mater "regard-less of the leadership" and whether or not their alma mater proved itself worthy.

Interestingly, low givers also indicated that "regardless of their treatment" as an "undergraduate or an alumnus/a," they would continue to support their alma maters.

\section{Giving Behaviors}

Giving behaviors have had various impacts on the development functions and activities of HBCUs. In this section of the questionnaire, alumni were asked to indicate their preferred behaviors of giving. This included behaviors such as contributing to scholarships, participating in a planned giving program or considering contributions through direct deposit, and giving as a result of clear and concise goals.

The findings suggested that the majority of alumni, both high and low givers, would be more likely to support "funds" such as scholarships; however, there appeared to be a lack 


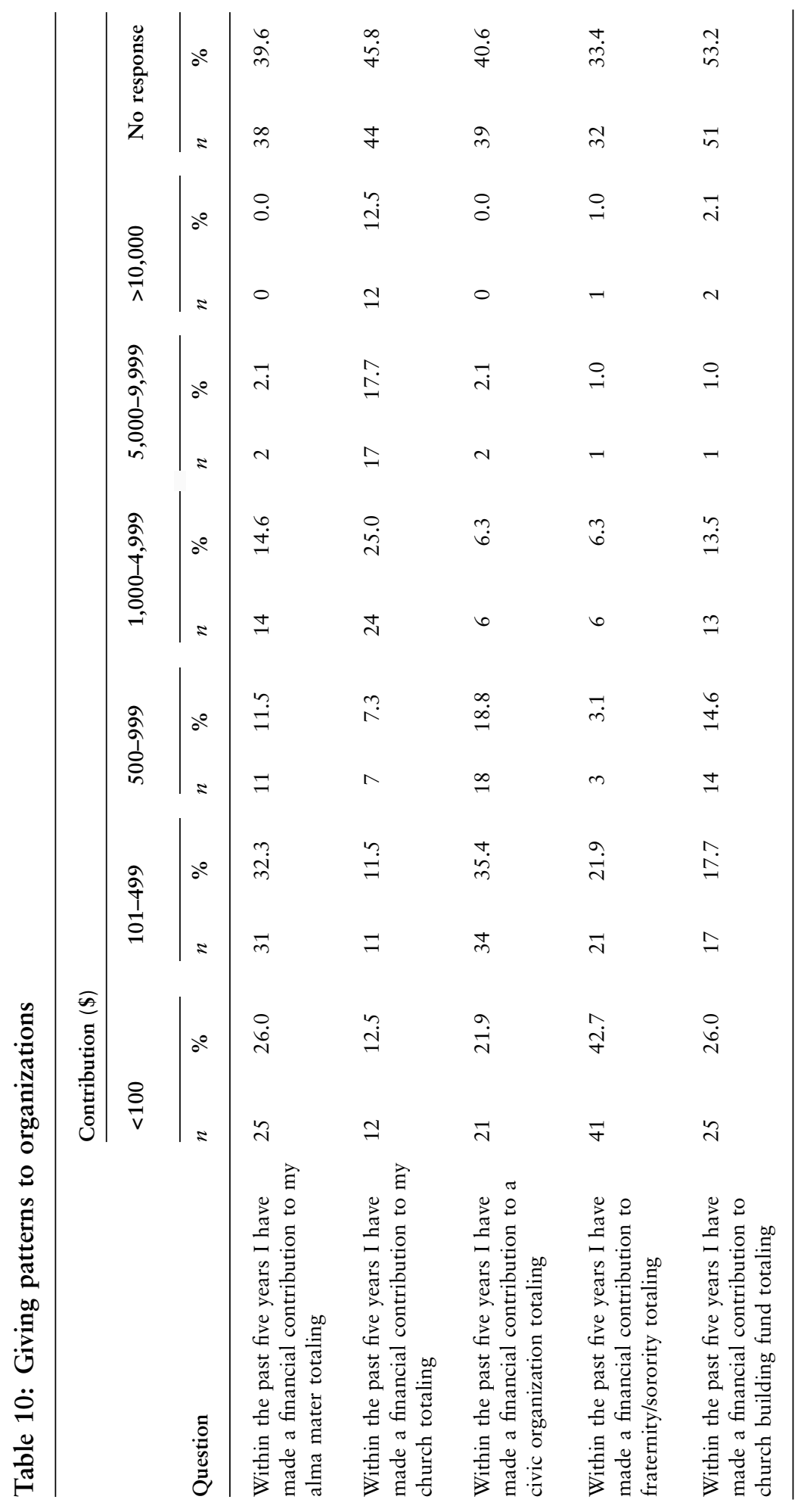


of interest in giving money through "direct deposit" (see Tables 8 and 9). In terms of planned giving, the majority of low givers indicated that given the opportunity, "they would leave a portion of their will" to their alma maters.

Again, when looking at "obligatory giving" as a behavior, there also existed a difference between the high and low givers. Consistent with previous sections, the majority of low givers feel that supporting one's alma mater is an "obligation and that everyone should participate." Not too surprisingly, a significant percentage of high and low givers indicated that if there are "clear and concise fundraising goals" and they "knew what the money was to be used for" they would be more likely to give.

\section{Giving Patterns}

The fifth research question was concerned with the relationship between the level of alumni giving and giving patterns to other organizations. These institutions included civic groups, fraternal groups, and the church. Alumni were asked to indicate their financial contributions to each organization, within a five-year period, in the following amounts: $\$ 100$ or less, \$101-\$499, \$500-\$999, \$1,000$\$ 4,999, \$ 5,000-\$ 9,999$, and $\$ 10,000$ or more. Tables 10 and 11 present the results.

With regard to financial giving to the church and civic groups, there existed a measurable difference between high givers and low givers. With regard to contributions to fraternal groups, there did not exist a measurable difference between high and low givers. Somewhat consistent with giving to their alma mater, high givers were also high givers to their church and civic groups, with the highest percentage of giving existing within the church. High giving to the

Table 11: $t$-test analysis: giving patterns to organizations

\begin{tabular}{|c|c|c|c|c|c|}
\hline Variable & $n$ & M & $t$-value & df & $p$-value \\
\hline \multicolumn{6}{|c|}{ Within the past five years I have made a financial contribution to my church totalling } \\
\hline High givers & 56 & 3.98 & 2.36 & 0.77 & $0.021 *$ \\
\hline Low givers & 23 & 3.04 & & & \\
\hline \multicolumn{6}{|c|}{ Within the past five years I have made a financial contribution to a civic organization totalling } \\
\hline High givers & 56 & 2.44 & 4.12 & 0.76 & $0.001 * *$ \\
\hline Low givers & 22 & 1.50 & & & \\
\hline \multicolumn{6}{|c|}{ Within the past five years I have made a financial contribution to fraternity/sorority totaling } \\
\hline High givers & 50 & 1.88 & 1.34 & 0.67 & 0.183 \\
\hline Low givers & 19 & 1.47 & & & \\
\hline \multicolumn{6}{|c|}{ Within the past five years I have made a financial contribution to church building fund totaling } \\
\hline High givers & 49 & 2.63 & 2.74 & 0.67 & $0.008 * *$ \\
\hline Low givers & 20 & 1.70 & & & \\
\hline
\end{tabular}

"Significance $<0.05$, two-tailed

* Significance $<0.01$, two-tailed 
church existed at $3 \frac{1}{2}$ times the rate of the high giving that existed at one's alma mater, with more than 10 times more giving at the highest level-\$10,000 or more-going to the church than to one's alma mater.

High givers, on the other hand, gave less at the high giver level to their civic groups than they did the church and their alma mater. Both high and low givers, however, fell in the low givers category when making financial contributions to their fraternity, sorority, or lodge.

\section{Conclusions and Recommendations}

There are now African Americans who recognize that for 200 years most black giving was crisis driven. Now, however, there is a critical mass of ... [black] people who understand that you can give strategically ... and give through structured endowments, wills, or bequests. (Carson, quoted by Lewis, 2000, n.p.)

As many of America's HBCUs continue to face the threat of closure, the issue of alumni support continues to be of major concern. The future of these colleges is inextricably linked to the degree to which they are successful in engaging their alumni in the philanthropic process. The need for HBCUs to enhance their alumni programs is vital if they are to sustain their important role in American higher education.

This study concerning the attitudes, perceptions, and giving behaviors among black college alumni reveals information that may be of assistance to future black college fund-raising efforts. Its importance is grounded in the fact that many studies conducted on African American philanthropy have often been unfamiliar with the pattern and traditions of minority giving (Brittingham and Pezzullo, 1990).

Engaging HBCU alumni to participate in philanthropy is an important task for uncovering emerging alumni donor capacity atypical to most of these institutions. Heretofore, many HBCUs have relied on other sources such as corporations and foundations to keep the doors open. The data produced by this study underscores the need for HBCUs to take their alumni base seriously and re-examine the method by which they are engaged.

The data do not describe the exact solutions to all the problems facing black college fund raising or the many challenges involved with cultivating this unique group of alumni. These data, however, can broaden the knowledge and understanding of the many misunderstood and neglected issues associated with cultivating black college alumni.

This study provides a broad insight into some general nuances associated with attitudes, perceptions, and giving behaviors. It also provides black college development officers, administrators, and future researchers with a foundation on which to build further research efforts at those HBCUs committed to improving their alumni fund-raising efforts. Black college administrators, development professionals, researchers, and alumni must work harder to utilize the type of information revealed in this study to overcome the myths and stereotypes associated with black alumni fund raising. 
The findings in this study, consistent with other studies, suggest that African Americans do express a "generous" desire to give. As would be expected with high givers, the attitude or desire to give is expressed more among the low givers in this study. This raises an interesting concern regarding cultivation. If low givers feel financially able to give and are giving at the low level, institutions should then look to their area of advancement services and research the level at which many of these low givers are truly able to give.

If low giving is a result of limited cultivation and research, these data provide an opportunity for HBCUs to reconsider the efforts and energy they place on their low givers. In addition, the findings support that alumni materials and literature have no real effect on giving, suggesting that giving may in fact be a result of some other type of motivation. With the looming challenge of limited resources for development activities at many HBCUs, it may be plausible for these colleges to review their traditional methods of communication and solicitation and consider a more personal approach, also suggested by previous studies on African American solicitation.

Surprisingly, a strong desire to support one's alma mater appears to exist regardless of factors such as institutional leadership (who is in charge), one's treatment as an undergraduate, or one's treatment as an alumnus/a. This "obligatory type" of giving should be further investigated to uncover those factors and indicators that cause an almost absolute type of support. Black college alumni have many times been defined as "die-hard" alumni. This die-hard type of attitude towards the desire to support "regardless" should be viewed as a positive and should not be taken for granted. These individual types should also be enlisted as volunteers and advocates to assist their alma mater in recruiting others for alumni involvement. This is an interesting finding in that, in the African American community, the notion of obligatory giving and responsibility is usually thought to exist for the church and not one's alma mater.

Similar to the idea of obligatory giving, African American alumni in this study view "giving back" as more than just making a financial contribution. Consistent with other studies, which have shown that African Americans view giving and support as a community and communal support, the notion of giving takes on a different meaning. Overwhelmingly, alumni in this study indicate that they would send their child or relative to their alma maters and, if they could return to college, they would attend their alma maters again.

Sending a loved one to one's alma mater may be a way in which an institution can view a type of predonation. Because many HBCUs are tuition driven, the idea of paying tuition could serve as a topic for future philanthropy through scholarships and other types of institutional academic support. This would parallel other findings in this study that support the fact that African Americans are prone to supporting scholarship funds.

Involving alumni as parents and relatives of students in school 
provides the foundation for alumni to begin to view themselves as "investors" and not just "helpers" in the giving process. The development of an investment can then be used to cultivate and engage others not involved in the tuition process, for example. Unfortunately, findings in this study suggest strongly that there is the perception that one's alma mater can survive in the future without financial support from alumni. This is more interesting because the findings also suggest that many of the alumni perceive their alma mater's endowment and funding to be insufficient.

The perceived disconnect, again, could be addressed when alumni view themselves as "life-long" stakeholders and not donors of charity. In this situation, the HBCU must develop a strong case as an institution worthy of its alumni's investment. Developing, again, the ongoing personal contact that educates and informs the alumni base of the fact that no institution, whether it is Harvard or Howard, can survive in the future without the lifelong support of its alumni is vital. These institutions must convey the fact that mere existence is not synonymous with financial stability or prosperity. In fact, the case has to be made consistently regarding the amount and type of resources required to maintain and evolve a college or university of any size.

Probably the most interesting part of the findings is that of the actual contributions. With regard to giving patterns, the verdict remains the same. The majority of the dollars donated by African Americans continue to go to the church. This is a fact that probably will not change in the near future. The fact is that religion has and will continue to be the "mother of all philanthropy." With this in mind, HBCUs need to develop a stronger relationship with their respective denominations and congregations.

During the early development of HBCUs, the church was the sole supporter of many of these colleges. Similar to corporations and foundations, the church can no longer be the sole provider of funds. However, a formal structure can be developed that allows, at least at church-related colleges, HBCUs to formally cultivate the alumni and congregations of their respective denominations. At one time, many of these colleges had an office or individual dedicated to church relations. A similar system implementing the formal techniques of development should be developed at these colleges. Again, feeding off the obligatory giving pattern of the church, these colleges can blend a development program that borrows some of the formal techniques present in the church.

Even though the findings of this study derive primarily from four specific four-year HBCU institutions and a select group of alumni (i.e., donors), other HBCUs and educational funding groups such as the United Negro College Fund and the Thurgood Marshall Fund can benefit from these findings. Further questions have arisen from this study that might prove valuable for future research and discussion. For example, although there is value in understanding the attitudes and perceptions of those currently supporting their alma 
maters, it seems to me even more important to look at those who are not stakeholders at all. I suspect a different set of results would derive from such study, which could provide an interesting comparison and contrast of donors versus nondonors.

Additionally, future research could be concerned with the specific attitudes and perceptions of and within individual colleges or universities. In this study, results were gathered and commingled across institutional types. It might prove beneficial, however, to look at colleges/universities on a caseby-case basis, or at least by groupings of institutional types. These institutional types should, however, borrow from current research efforts that describe the groupings of HBCUs unique to this class of colleges and universities. The current utilization of Carnegie classification would not provide the best categorization due to the uniqueness of HBCUs that Carnegie does not include.

Finally, future research on individual HBCU alumni constituent groups should be considered for two reasons. First, most black colleges are resource poor and do not possess the luxury of funds for high-level development activities. Therefore, the best possible approach for alumni development needs to be development based on scientific facts from research and not just on mere replication of development models at majority institutions. Second, each HBCU interested in conducting serious study of its alumni must conduct an internal study, either through the enlistment of its own faculty or by retaining a researcher for their use. This is imperative because, outside of the student population of a college or university, the alumni database is one of the most protected lists of people at an institution. As evidenced by this study, it is very difficult for outsiders to gain access to alumni and alumni databases; therefore, it would be best served for the institution itself to conduct this study.

Finally, although this is a challenging area of research, the rewards are immeasurable, not only to the institutions that will benefit but also to the development profession in general. As African Americans continue to make economic strides in society, there is an increasing need to specifically understand this group with regard to academic fund raising. Since the 1930s when many black colleges began to increase their numbers in the alumni ranks, black colleges have been strategically negligent in efforts to acknowledge their own and in producing development-savvy measures to garner their wealth. The results of this study provide a research base upon which both robust discussions within black colleges and ideas for further study by researchers in this most neglected area can arise.

\footnotetext{
References

Alumni of black colleges are unable to relieve the financial squeeze (1996), Journal of Blacks in Higher Education, 65, n.p.

Aptheker, H. (ed.) (1973), The Education of Black People, University of Massachusetts Press, Amherst.

Bremond, W. (1976), "The national black united fund movement, The Black Scholar, 7, 6, pp. 10-15.

Brittingham, B. and Pezzullo, T. (1990), The Campus Green: Fundraising in Higher Education (ASHE-ERIC Higher Education Report No. 1) George Washington University, Washington, DC.

Byrd, K. (1999), "Alumni donations lag at black schools: Funding has increased, but trails gifts
} 
at white colleges, Philanthropy News Digest, Retrieved June 1, 1999, from http://fdncenter. org/pnd/archives/19990601/002724.html.

Clotfelter, C.T. (2000l), "Alumni giving to elite private colleges and universities", unpublished manuscript, Duke University.

Eckel, C. and Grossman, P. (1998), "Are women less selfish than men? Evidence from dicator experiments, Economic Journal, 448, 108, pp. 726-735.

Fund-raising pressures plague $\mathrm{HBCU}$ presidents (2002), Houston Defender, 71, 45, p. 3.

Gasman, M. (2002), “An untapped resource: Bringing African Americans into the college and university giving process, CASE International Journal of Educational Advancement, 2, 3, pp. 280-290.

Hodgkinson, V. and Weitzman, M. (1992), Giving and Volunteering in the United States., Independent Sector, Washington, DC.

Lee, S. and Jones, L. (1988), Uplift the Race: The construction of School Daze, Simon \& Schuster, New York.

Lewis, D. (2000), “African American philanthropy on the rise, Philanthropy News Digest, Retrieved January 21, 2001, from http:// fdncenter.org/pnd/20000627/003469.html.

Miller, D. and Salkind, N. (2002), Handbook of Research Design and Social Measurement, 6th edn. Sage, Thousand Oaks, CA.
Okunade, A. (1996), "Graduate school alumni donations to academic funds: Micro-data evidence, American Journal of Economics and Sociology, 55, pp. 213-229.

Russell, C. and Kasberg, R. (1997), African American Traditions of Giving and Serving: A Midwest Perspective, Indiana University, Center on Philanthropy: Bloomington.

Seymour, H.J. (1992), Designs for Fund-Raising: Principles, Patterns, Techniques, 2 nd edn. McGraw-Hill, Rockville, MD.

Shadoian, H. (1989), "A Study of Predictors of Alumni in Public Colleges", unpublished doctoral dissertation, University of Connecticut.

SPSS (1999), SPSS Base 10.0 User's Guide, Author, Chicago.

Stutler, D. and Calvario, D. (1996), "In alumni support, satisfaction matters, Fundraising Management, 27, p. 12.

Wallace, D. (1954), “A case for-and againstmail questionnaires, Public Quarterly, 18, pp. 40-52.

What is happening at colleges and universities? (2003), Occasional Papers of Bentz, Whaley, o Flessner, 13, pp. 1-4.

Winbush, D. (1996), "Spelman mission was not impossible: How college's fundraising drive netted \$113 million, Black Issues in Higher Education, 13, 15, p. 18. 